DOI https://doi.org/10.30525/978-9934-26-180-0-24

\title{
STRUCTURAL PECULIARITIES OF SUBSTANTIVE PHRASEOLOGICAL UNITS WITH AN ANTHROPONYMIC COMPONENT IN MODERN ENGLISH
}

\author{
Tiurina K. O. \\ 4th year student at the Department of Humanities and Social Studies \\ Poltava State Agrarian University \\ Poltava, Ukraine
}

Worldview is a basic concept that reflects specificity of individual and their interaction with the world. It is a multilayered structure within which various types of worldviews are in hierarchical relationship with each other.

A worldview is formed historically by each speech community and fixed in its language. Thus, one of the main substructures that fixes panhuman and national socio-historical experience is linguistic worldview that has a language - principal means of communication between individuals as well as the main way of storing and transmitting information through the generations - as the leading component.

Linguistic worldview that is represented in any language is inextricably intertwined with phrasicon because phraseological units are those linguistic universals without which no language can exist.

According to S. Vetchinnikova, Lecturer at the University of Helsinki [12, p. 12], idioms are the mirror that reflects national morale of linguistic and cultural community; precisely phraseological units impose specific views of world and situation on native speakers.

Phraseological unit is a modeled collocation that is the product of linguistic folk art whose meaning isn't determined by the meanings of separate components it consists of and is a single part of a sentence.

We believe that the widest range of idioms is represented in the English language the culture and history of native speakers of which is particularly rich and bright.

Having analysed the works of such scientists as A. P. Cowie [2], P. M. Huerta [6], B. Kipfer [7], B. Schlücker [9] and R. Soule [11], we have established that in the English language, there is a symbiotic relationship between the concepts of «phraseological worldview» and a «man», that has been existing since ancient times. It was the appearance of a man and their vigorous activity that contributed to the emergence of such a linguistic phenomenon as the idiomatic treasury of a language, which in the process of their 90 
anthropogenesis was constantly replenished with new elements. Hence, we can safely say that the anthroponym is an essential part of the idiomatic expressions of the English language.

Anthroponymics is an onomastic science whose research focuses on proper names, mainly names of people, nicknames of animals and names of literary characters, which in linguistics are called «anthroponyms».

Based on the powerful connection between an «idiom» and an «individual», we suppose that it's important to study phraseological units of the English language in terms of the anthroponymic paradigm to explore all their peculiarities.

Having studied such sources as The Oxford Dictionary of Idioms [1], The Great Book of American Idioms: A Dictionary of American Idioms, Sayings, Expressions \& Phrases [8] and Thesaurus of English Idioms [4], we've concluded that exactly noun is a leading grammatically independent component of the majority of English idioms.

The target of our research is to analyse substantive phraseological units of the English language with an anthroponymic component, and the scope of our research is to study their structural peculiarities.

At the present stage of the development of linguistics, in particular phraseology, the structural peculiarities of idiomatic expressions of the English language with an anthroponymic component are an understudied phenomenon, which determines the thematic justification of our research.

Substantive phraseological units are lexical chunks with fixed and metaphorical meaning that have a noun as a leading component, indicate the objectification and function as a subject, an object or a nominal part of the compound predicate in a sentence.

Having analysed the phrasicon of the English language, in particular the structural peculiarities of substantive phraseological units with an anthroponymic component, we've concluded that there are seven principle groups of substantive-anthroponymic idioms in modern English.

1. Idioms expressed in the format of «noble title/ social status/ social role + anthroponym»:

- Mrs Grundy [10, p. 68] - a Janus-faced, or hypocritical person who shows false piety in order to achieve their own targets;

- Aunt Sally [1, p. 12] - a person who is always offended by other people;

- Uncle Sam [8, p. 178] - the U.S. government. It may be also used as a name of this country.

2. Idioms expressed in the format of «anthroponym + possessive case + noun»: 
- Frankenstein's monster [1, p. 49] - something that annoys us and is a reason of many problems; pain in the neck;

- Murphy's law [10, p. 72] - the rule of life which says that if something may go wrong, it'll go for sure;

- Hobson's choice [4, p. 136] - a single choice.

3. Idioms expressed in the format of «anthroponym + noun»:

- Judas kiss [5, p. 52] - a symbol of betrayal;

- Midas touch [1, p. 63] - a person who is capable of making a lot of money in an easy way;

- Sisyphean labour [1, p. 94] - hard and fruitless labour.

4. Idioms expressed in the format of «adjective + anthroponym». Despite the fact that in the idiomatic expressions like that there is an adjective, which is intended to indicate a feature of the subject, but not the subject itself, these idioms are substantive, as they are inseparable word-combinations and in tandem indicate precisely the objectification:

- tin Lizzie [1, p. 115] - a cheap old car;

- simple Simon [8, p. 164] - a simple-minded person who is not very intelligent and who can be easily deceived; simpleton;

- smart Alec [10, p. 125] - an excessively vainglorious and narcissistic person who thinks they know more than the rest people do.

5. Binomials expressed in the format «anthroponym + conjunction + anthroponym»:

- Damon and Pythias [4, p. 79] - best friends who never leave each other in their hours of need;

- Darby and Joan [3, p. 38] - married couple who love each other to bits and live together for a long period of time.

6. Trinomanals expressed in the format «anthroponym + anthroponym + conjunction + anthroponym»:

- Tom, Dick and Harry [3, p. 125] - an ordinary person, any person, everyone;

- Browns, Joneses or Robinsons [4, p. 58] - ordinary people who are not particularly popular.

7. Compound idioms with an anthroponymic component:

- Johnny-come-lately [8, p. 48] - a newcomer;

- Johnny-on-the-spot [10, p. 32] - a person who always shows up on time in the right place.

Thus, in our work we've presented the structural peculiarities of substantive phraseological units with an anthroponymic component in modern English having divided these idiomatic expressions into seven groups. The classification is based on the principal features of the structural elements of the substantive- 
anthroponymic idioms, which include the semantics of the structural components, their belonging to a particular part of speech, the quantitative composition of the proper names, the type of word formation (compounding) as well as the presence of some additional linking elements (possessive case, conjunction).

\section{References:}

1. Ayto J. The Oxford Dictionary of Idioms. Fourth Edition. NY: Oxford University Press, 2020. 448 p.

2. Cowie A. P Phraseology: Theory, Analysis, and Applications: Theory, Analysis and Applications (Oxford Studies in Lexicography and Lexicology). Seattle, 2001. 272 p.

3. Flavell R., Flavell L. Dictionary of Idioms and Their Origins / Flavell R., Flavell L. London: Kyle Books, 2008. 256 p.

4. Nagy G. L. Thesaurus of English Idioms. Kuala Lumpur: Tinta Publishing House, 2006. 1249 p.

5. Gulland D. M., Hinds-Howell D. G. The Penguin Dictionary of English Idioms. London: Penguin Books, 2001. 400 p.

6. Huerta P. M., Albaladejo-Martínez A. Fraseología, Diatopía y Traducción / Phraseology, Diatopic Variation and Translation. Amsterdam: John Benjamins Publishing Company, 2018. 360 p.

7. Kipfer B. Phraseology: Thousands of Bizarre Origins, Unexpected Connections, and Fascinating Facts about English's Best Expressions. Naperville: Sourcebooks, 2008. 320 p.

8. Lingo Mastery The Great Book of American Idioms: A Dictionary of American Idioms, Sayings, Expressions \& Phrases. Independently published, 2019. 229 p.

9. Schlücker B. Complex Lexical Units: Compounds and Multi-Word Expressions. Berlin: De Gruyter, 2019. 538 p.

10. Sharma M. Dictionary of Idioms. New Delhi: Prabhat Prakashan, 2021. $286 \mathrm{p}$.

11. Soule R. A Dictionary of English Synonymes and Synonymous or Parallel Expressions Designed as a Practical Guide to Aptness and Variety of Phraseology. Seattle, 2011. 478 p.

12. Vetchinnikova S. Phraseology and the Advanced Language Learner. Cambridge: Cambridge University Press, 2020. 440 p. 